\title{
Compressing Time and Constraining Space: The Contradictory Effects of ICT and Containerization on International Shipping Labour*
}

\author{
Helen Sampson and Bin Wu
}

\section{INTRODUCTION}

The twentieth century has been a period of rapid change in terms of production and consumption, work, and employment. Much of this change has been driven by developments in technology or the application of new technologies to existing production systems and ways of ordering and organizing work. In characterizing such change, Schumpeter popularized the term innovation. ${ }^{\mathrm{I}}$ In viewing innovation as the main engine of economic growth, Schumpeter was interested in the idea of the entrepreneur as innovator, not simply in terms of an agent for the introduction of new inventions but more broadly as an organizational innovator introducing new systems of work, new products, and new forms of production.

The early twentieth century saw the introduction of mass production systems, by entrepreneurs such as Henry Ford, and an associated growth in patterns of mass consumption. However, by the end of the century there had been a shift away from enterprises maximizing economies of scale through the mass production of individual goods towards more flexible "just-in-time" systems, increasingly demanding flexible workers,

\footnotetext{
* We are very grateful to the staff of the Tetra terminal in Rotterdam for their time and help and for allowing us to gain an insight into the operation of a deep-sea container terminal. We are also grateful to all the seafarers that took part in the research informing this paper over a three-year period. We would like to thank the staff of the anonymous short-sea terminal who allowed us to visit and observe their operations as part of the background research to the study. In terms of the writing of the paper we have appreciated the comments and encouragement of Huw Beynon, Aad Blok, and Greg Downey, and the inimitable critique of Tony Lane. We would like to thank the ESRC and SIRC for funding the research we have drawn on in producing this paper. Final thanks are due to Phil Belcher, Mick Bloor, and Erol Kahveci for their contributions to data collection. See also Erol Kahveci, Tony Lane, and Helen Sampson, Transnational Seafarer Communities (Cardiff, 2002).

I. Joseph A. Schumpeter, Capitalism, Socialism, Democracy (New York [etc.], I942).
} 
geographic flexibility in plant placement, and access to new and distant markets for less durable and more fashion dependent goods. ${ }^{2}$

The introduction of such forms of production and consumption (termed postmodern by some) combined with, and were to a great extent dependent upon, the technological revolution that accompanied them. Thus "just-intime" systems required excellent information and communications systems to be effective. Similarly, in the search for flexible workers and access to new markets, many companies went "global", and the world of many workers and increasing numbers of citizens underwent a transformation resulting from what has been referred to as "time-space compression". ${ }^{3}$ This phenomenon is said to leave individuals with a sense of the world getting smaller, as many are able to traverse space at ever increasing speeds, and send and receive information at the touch of a button, or more likely, the click of a mouse. Harvey illustrates the notion of time-space compression using the example of a shrinking globe; he explains:

The time taken to traverse space [...] and the way we commonly represent that fact to ourselves [...] are useful indicators of what I have in mind. As space appears to shrink to a "global village" of telecommunications [...] and as time horizons shorten to the point where the present is all there is [...] so we have to learn to cope with an overwhelming sense of compression of our spatial and temporal worlds. 4

Thus, for many people the accessible space of the everyday world can be seen to have expanded as a result of cheaper and more rapid systems of transportation. In addition, time may be perceived as having "speeded up", both in terms of the pace of everyday life, and the time it takes to communicate over long distances in the context of what is increasingly a twenty-four hour global society. Such changes cannot be seen as uniform, however, as they impact on different individuals and groups in varying ways. Most notably, poverty excludes many from the "global village" characterized by Harvey, whilst time horizons do not inevitably shrink for all, and indeed unemployment, imprisonment, or entrapment in tedious and monotonous work may do much to stretch them. Given such variability, and the centrality of transport in the process underpinning time-space compression, it seems apposite to consider the experiences of transport workers in the context of their work traversing the globe at incrementally increasing rates. Intriguingly seafarers, at the forefront of modernization, given their role in the mass transportation of freight, may be seen to have been pioneers in the process of time-space compression. Their experiences highlight the very ways in which time and space is

2. David Harvey, The Condition of Postmodernity: An Enquiry into the Origins of Cultural Change (Cambridge, MA [etc], I990).

3. Ibid.

4. Ibid., p. 240. 
affected by the changes in systems of transportation, transforming both the spatial and the temporal world.

In the late twentieth century, the seafarer labour market, which was always, to some extent, global in scope, became increasingly organized on an international basis with the development of crew supplying agencies and management companies in developing countries such as India, the Philippines, Myanmar, Indonesia, and, most recently, China. Thus, whilst investment in shipping has remained largely in the "West" the supply of labour has increasingly moved "East". Movements away from labour markets in the developed world (including Japan) have been accompanied to some extent by a "deterioration" in the employment conditions of seafarers. Whilst differences exist in the opportunities offered to seafarers from different parts of the world, many of today's seafarers, including officers, are employed in relatively deregulated labour markets with little or no job security. They are increasingly employed by ship-management companies and paid on a per-voyage basis, thus increasing the ease with which they can be hired and fired. Thus, modern ships are generally populated by multinational crews of seafarers, many of whom are employed on short-term contracts, and all of whom operate in a highly time-space compressed environment. Modern vessels plough the seas at increasingly rapid rates. A container vessel today might be expected to travel at an average speed of 22 knots, whilst in the I960s a similar ship would have had an average speed of approximately is knots. Thus, a new Filipino cadet today may find himself whisked away from his provincial home, flown halfway round the world to join a vessel, only to be sailing the coastal waters of his homeland within a month, having "visited" six or seven ports. Such mobility is deceptive, however, as the world cannot be seen as becoming more accessible to the seafarer even as it becomes compressed. Indeed, the evidence is of the opposite trend, and in many ways the spatial world of the seafarer can be seen to have contracted.

These phenomena and their underlying causes are amongst the issues considered in this paper. Time and space are experienced differently by people in different contexts, cultures, and circumstances. Whilst we might objectively measure both space and time, our sense of these and what they mean alter according to our situations. This paper will argue that, curiously, as a result of increased separation from shore and associated isolation, monotony, and boredom, in some respects modern seafarers have more in common with seafarers of the late nineteenth century than they do with seafarers in the I950s and I960s. In the days of early sailing ships, seafarers could be out at sea for months without sight of land or indeed another sail. They typically experienced feelings of isolation and boredom and could be tremendously uplifted by the sight of the shore or another ship, as Franklin described in I 726 when recounting his "tedious" voyage from Southampton to Philadelphia: 
There is something strangely cheering to the spirits in the meeting of a ship at sea, containing a society of creatures of the same species and in the same circumstances with ourselves, after we had been long separated and excommunicated as it were from the rest of mankind. My heart fluttered in my breast with joy when I saw so many human countenances, and I could scarce refrain from the kind of laughter which proceeds from some degree of inward pleasure.5

For very different reasons, modern seafarers are similarly removed from land and often have a similar sense of space and time. Whilst working conditions, wages, and standards of health and hygiene have improved across the industry, seafarers in the twenty-first century once again find their lives at sea to be characterized by isolation, tedium, and confinement. They too experience a sense of "excommunication" and separation. As an oiler involved in our ethnographic study aboard one vessel explained: "[It's] like a prison. You eat and then you work [...]. Yes, like a prison. You don't go ashore."

\section{METHOD}

This paper draws on the preliminary findings of a pilot study undertaken by Sampson in the Port of Rotterdam at two modern container terminals. The study involved the analysis of secondary data and visits to two modern container terminals - one engaged in short-sea, and one engaged in deepsea trade. This was followed by an ethnographic study of the Tetra deepsea container terminal, 7 incorporating in-depth tape-recorded interviews with terminal employees (largely in supervisory or management grades), with a terminal-based representative of the shipping line, and with senior officers aboard vessels calling at the terminal in the course of the week. Additionally, the paper draws on the findings of seven ethnographic research voyages undertaken as part of an ESRC-funded project on transnational seafarer communities (ESRC ref: L2 I 4252036 ). In the course of these, seafarers of all ranks and varying nationalities took part in detailed tape-recorded interviews focusing on life and work aboard, rigorous fieldnotes were maintained, and a photographic record kept. The paper draws on all of these sources in considering the technological and organizational changes in shipping that have been associated with the "speed-up" of voyages and/or cargo operations, and the impact these have had on the lives and work of seafarers.

5. Benjamin Franklin, "Journal of a Voyage", in Jonathan Raban (ed.), The Oxford Book of the Sea (Oxford, 1992) pp. 92-107, 100.

6. Oiler: interview with Sampson. NB - an oiler is the equivalent rank to an able-bodied seafarer but oilers work in the engine room rather than on deck.

7. The terminal name has been altered to protect anonymity and confidentiality. 


\section{B A C K GR OUND}

Shipping has a long history inherently characterized by innovation and change. In Britain, for example, people first navigated waterways and sheltered seas in canoes. ${ }^{8}$ Subsequently, sailing ships dominated ocean transport for several centuries. However, by the early part of the nineteenth century some had become steam-assisted, with the introduction of (increasingly efficient) coal-fired boilers. Full steam power followed on closely from these hybrid vessels and this mode of power persisted for approximately a century. By the mid-twentieth century, however, steam ships had generally been replaced by those with diesel-fed engines. The internal organization of the ship altered too, and in some dramatic ways. The introduction of an engine required radical transformations aboard, as engineers, firemen, and watertenders were added to the ranks of seafarers, ${ }^{9}$ and a chief engineer was put in charge of them. This change affected the organization on board so dramatically that seafarers today still refer to a "divide" between engineers and navigation officers, making ironic use of the cliché that "oil and water don't mix". There were significant changes on the bridge too, with advances in navigation and the introduction of revolutionary pieces of equipment such as radar and, much later, satelliteassisted global positioning systems.

This process of transformation and the uptake of available innovative technologies in merchant shipping was both gradual and uneven. The first steam ship to cross the Atlantic was sail-assisted and was built in New York in I8I9. She was rapidly followed by faster steam-powered vessels ${ }^{10}$ and the development of more efficient systems of propulsion, (screw rather than paddle). ${ }^{\text {II }}$ However, many companies were reluctant to invest in unproven new technologies. Sailing ships continued as deep-sea merchant traders until as late as 1929 and sailing barges known as "boomies" or "dandys" continued with continental trade right up until, and during, World War II, when diesel-fuelled motor coasters were already dominant in the same trades. ${ }^{\mathrm{I} 2}$ Thus, the transition from sail to steam and then to diesel ships, and from wooden to metal hulled vessels, was a slow one characterized by overlap rather than fracture.

Similarly, the up-take of innovation in navigation, information, and

8. Hubert Moyse-Bartlett, From Steam to Sail: the Final Development and Passing of the Sailing Ship (London, I946).

9. Mariam G. Sherar, Shipping Out: A Sociological Study of American Seamen (Cambridge [etc.], 1973).

I0. Alfred George Course, The Merchant Navy: A Social History (London, 1963).

I I. The first screw-propelled ships came into service in the early i 840 s, the largest of these early vessels combining sail and steam being The Great Northern and The Great Britain, launched in I 842 and 1843 respectively. See Stephen Fisher (ed.), Innovation in Shipping and Trade (Exeter, I989).

I 2. Tristan Jones, A Steady Trade (London, 1984). 
communication, technologies has varied. Today, a modern container vessel such as those included in the Rotterdam pilot study might have automated computer-monitored engines, sophisticated (ARPA) radar systems, satellite communications, ${ }^{13}$ Global Positioning Systems (GPS), Electronic Chart Displays (ECDIS), internet access, e-mail, and access to satellite and mobile telephones. Additionally, it is likely to carry cargo-monitoring equipment, and software programmes for ballasting and stress calculations, replacing the requirement for seafarers to be directly involved in measuring cargo temperatures or taking soundings. This contrasts dramatically with what one might find aboard an older refrigerated vessel or a bulk carrier. Here, one ship included in the ethnographic research undertaken by Sampson did not have access to any satellite telephone communication and relied on VHS radio posts to make periodic telephone contact with the world. This vessel had few computers aboard, little software of any kind, and no e-mail. None of the five ships boarded by Sampson in the period 1999-200I had electronic charts (ECDIS) and all relied on chief officers rather than shore-side staff for stress calculations and cargo planning. Thus, in the modern context it is also clear that, in terms of innovation, some companies lead whilst others lag behind. These differences between ships and shipping company practices are constrained to some extent by national, and increasingly international, regulation that requires certain standards, practices, and equipment on board deep-sea cargo vessels. This is not a new phenomenon. In the UK, for example, the requirement to maintain a radio watch on all British vessels was established in I919 following the high-profile loss of the Titanic. Such national regulation has increasingly been supplemented and underpinned by international requirements, such as those introduced by the 1948 International Safety of Life at Sea Convention and, more recently, amendments to regulations relating to Standards in Watchkeeping and Certification (STCW '95) and the introduction of International Safety Management (ISM) systems.

The ship (like the factory) has therefore been transformed, and so too has the context in which it operates. The working lives and experiences of seafarers have altered and developed in line with changes in the organization of work both aboard and in port. Ships transport large amounts of materials between ports, and shipowners have always been aware of the significance of port handling for the profitability of their operations. The continuing pressure for shore-side automation and innovation has been driven by a number of concerns, and not least by pressure from shipowners who want their ships to be available to transport their next cargo at the earliest possible opportunity. A berthed ship is widely regarded by the industry as a waste of money, as it may incur expensive

I 3. Satellite communication was first introduced in the mid-i970s. 
port dues (as in early twentieth-century Rotterdam) and it is languishing rather than actively transporting cargo. As a shipping line representative in Rotterdam explained:

The [...] main thing is and the focus is always the vessel. That's our most expensive tool, apart from the people we have. So, if the [...] vessel's at sea, that's the only thing we aim at [...]. The vessel is the most expensive thing, and one of our [...] [particular vessel type] [...] is 3,500 US dollars an hour. So, if you keep a vessel idle for ten hours $[\ldots] !^{! 4}$

Thus, in the twenty-first century the fast turnaround of a vessel is as much a priority as it was in the early and mid-twentieth century, when mechanization and then automation were increasingly introduced. The efficiency of a terminal remains critical in determining the success of its client shipping lines, and it can make the difference between profit and loss. Is Alongside terminal operations, organizational innovation and change aboard ship has been required to ensure fast efficient shipping services and profitability in the global freight market. The experience of the Port of Rotterdam provides an excellent illustration of these processes.

\section{INNOVATION IN PORTS AND CARGO HANDLING OPERATIONS: THE CASE OF ROTTERDAM}

The city of Rotterdam is located in an important strategic position in terms of European trade and is currently the world's sixth largest container port (see Table I and Figure I overleaf).

Investment in the Port of Rotterdam began at an early stage, and in I 872 a waterway was constructed to facilitate shipping of increasing tonnage. In I 878, the construction and opening of the Binnehaven, the first basin on the south bank of the Maas, heralded the beginning of the seaward development of what is today a massive port, catering for a highly diverse range of ships and cargoes. ${ }^{16}$

The beginning of the twentieth century saw increasing mechanization within the port. Of major significance was the introduction of mechanized grain unloading. The consequences of this for the dock-labour force were immense. Many workers faced redundancy and unemployment and, as a result, organized a major strike against technical change. ${ }^{17}$ This strike, the

14. Shipping line representative: interview with Sampson.

15. Edmund J. Gubbins, The Shipping Industry: The Technology of the Economics of Specialisation (London, I986).

I6. Rotterdam Europort, "Port of Rotterdam: Characteristics of Rotterdam Port", Yearbook of Rotterdam Europort (Rotterdam, 1978).

17. Dick van Lente, "Machines and the Order of the Harbour: The Debate About the Introduction of Grain Unloaders in Rotterdam 1905-1907", International Review of Social History, 43 (1998), pp. 79-109. 
Table I. Top ten container ports $-200 I$

\begin{tabular}{clr}
\hline Rank & Place & \multicolumn{1}{c}{ TEU* } \\
\hline 1 & Hong Kong & $17,9000,000$ \\
2 & Singapore & $15,520,000$ \\
3 & Busan & $7,900,000$ \\
4 & Kaohsiung & $7,540,000$ \\
5 & Shanghai & $6,334,000$ \\
6 & Rotterdam & $6,129,000$ \\
7 & Los Angeles & $5,184,000$ \\
8 & Shenzen & $5,040,000$ \\
9 & Hamburg & $4,700,000$ \\
10 & Long Beach & $4,463,000$ \\
\hline
\end{tabular}

Source: ECT website 2002

* Twenty foot equivalent units

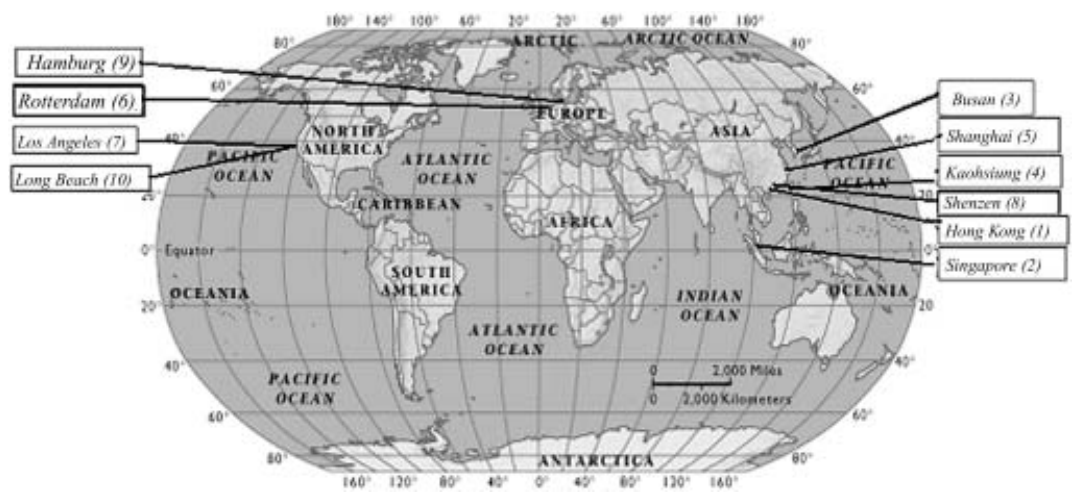

Figure I. Map illustrating location of top ten container ports.

first of two in the period 1905-1907, enjoyed success, but ultimately the grain unloaders, like the first electric cranes a decade earlier, were introduced and accompanied by a loss of jobs and a reduction in ship turnaround times.

Following these upheavals, there was no further major industrial unrest in the Port of Rotterdam for over fifty years. At this time, the introduction of another revolutionary set of changes aimed at reducing vessels' turnaround time, and relating to containerization, threatened the work and lives of port workers once again. ${ }^{18}$ Containerization was pioneered, in 
its current form, by the trucker Malcolm McLean in the USA. ${ }^{19}$ Traditional break-bulk ports in the I960s took some time in unloading and loading, and ships could be "idle" in port for periods of up to two weeks. ${ }^{20}$ Shipowners' dissatisfactions with such slow cargo-handling operations were exacerbated by the rising stevedore and port costs in the I950s and $1960 \mathrm{~S}^{2 \mathrm{I}}$ which were said to have resulted from wage inflation and rising port dues. ${ }^{22}$ McLean was inspired by transportation methods adopted by the US military, which allowed cargoes to be moved fluently from land to sea transport without the need for loading and unloading, much reducing the time a vessel was required to spend in port. He set up a company that he called Sea-Land and within a short space of time large Sea-Land vessels were crossing the Atlantic at impressive speeds. ${ }^{23}$ However, despite the rapid transition to containerization that took place on a world scale, the process had, and continues to have, a number of critics, ${ }^{24}$ some of whom have questioned why shippers have not made greater use of alternative cargo unitization, for example palletization. ${ }^{25}$

Dock workers and their trade unions had problems with containerization from its inception and there were a number of strikes and container boycotts by workers across the world (e.g. La Guaira in Venezuela, Tilbury and Liverpool in the UK, and Rotterdam in the Netherlands) in the I960s and I970s. The basis for opposition was often not the fact of containerization (which many considered part of the "inevitable" trend of progress), but was around wages, and the renegotiation of what constituted dock-work and what was defined as the docks. Here, technical innovation had been accompanied by changes in the social organization of work, as haulage contractors were attempting to "stuff and strip" containers beyond the traditional confines of the port. ${ }^{26}$ In this sense, such labour resistance cannot be regarded simplistically as a Luddite response to mechanization as Wilson explains:

[...] these were not instances of mere Luddite intransigence; they were linked to a wider policy of job protection in a period of rapid change, and in London, the

I9. However, containerization of various forms had previously been practised on a small scale in a number of world regions. See De Jong, Is There Any Future in Conventional Cargo Handling?. 20. Jeffrey Martin and Brian J. Thomas, "The Container Terminal Community", Maritime Policy Management, 28 (2001), pp. 279-292.

21. Robert Gardiner and Alistair Couper (eds), The Shipping Revolution: the Modern Merchant Ship (London, 1992).

22. Gubbins, The Shipping Industry.

23. The first container-only transatlantic voyage was undertaken by the Sea-Land vessel, Fairland, from the USA to Rotterdam.

24. See Rick Hogben, A Sharp Look-Out: One Hundred Years of Maritime History as Reported by "Fairplay" (London, 1983).

25. Gubbins, The Shipping Industry.

26. David F. Wilson, Dockers: The Impact of Industrial Change (London, 1972). 
aims of the Tilbury ban were always clearly stated: it was to remain until a package deal was negotiated, providing security for all dockers in the port [...]. ${ }^{27}$

Trade unions did not, therefore, oppose mechanization and automation per se, and were sensitive to international competition. ${ }^{28}$ They did, however, challenge the detail of containerization and sought, where possible, to maintain workforce levels. These were subject to remarkable global variation, being as low as three workers per gang in Rotterdam and seventeen per gang in New York.

Today, in Rotterdam stevedores may utilize crane gangs of between five and two workers and may average between twenty-five to thirty crane moves per hour. ${ }^{29}$ This is a significant increase in numbers of moves per hour on the early days of container terminals when productivity rates were averaging eighteen moves per hour. An experienced terminal manager described how this major increase in cargo-handling capacity directly results from computerization:

In those days [thirty years ago] you were talking about a productivity of eighteen, and that was the accepted norm. Then you also see changes over the years but that is taking a long time - you don't take quantum leaps, it's a very slow process [...]. Basically, it worked exactly the same but you didn't have the computer systems of today [...], and that's unthinkable nowadays, but as I said the norm in those days were about seventeen or eighteen [moves per hour] and today is about thirty or thirty-five. So its almost double in thirty years. $3^{3 \circ}$

These changes have combined with technical changes aboard ships to alter radically the ways in which life and work on board is organized and experienced. Here, as ashore, innovation in technology has been accompanied by other patterns of change associated with the social composition of the workforce and its organization.

\section{THE IMPACT OF INNOVATION IN THE TETRA TERMINAL}

The Tetra terminal is located in a vast isolated area of the port of Rotterdam dedicated to container loading and unloading. Container terminals owned by other operators flank it left and right, and to find it

\footnotetext{
27. Ibid., pp. I42-I43.

28. The strike in the Port of Rotterdam in I979 led to the diversion of cargoes and shipping lines to Antwerp and some custom never returned. See De Jong, Is There Any Future in Conventional Cargo Handling?.

29. Interestingly, fully automated straddle-carrier operations utilizing automated guided vehicles (AGVs) rather than human straddle-carrier drivers may be unable to increase their numbers of moves per hour to a level that would equate with slightly less automated operations using straddle-carrier drivers.

30. Tetra employee: interview with Sampson.
} 
you have to look hard, driving down avenues formed by stacks of containers up to nine boxes high. The terminal building is itself dwarfed by the containers surrounding it. It is a three-storey construction that rather resembles a large "portacabin". A number on the side of the building is all that identifies it and sets it apart from its "siblings" dotted along the waterfront.

The Tetra terminal is owned and managed by a company whose "parent" also owns a similarly named shipping line. This shipping line and its conference ${ }^{3 \mathrm{I}}$ associates are the main clients for the terminal. As a result, within the one building reside the Tetra terminal staff (a number of whom are ex-seafarers) engaged in managing, operating, and supporting the container terminal, and a small number of Tetra shipping-line staff responsible for providing "agency" services to vessels alongside. Such services include the organization of, bunkering, ${ }^{32}$ the provision of stores, crew changes, laundry etc. The area beyond the terminal building is known as the "yard", and it is here that reach-stackers and straddle-carriers" 33 operate, moving containers from and to the large cranes servicing the ships, and to land-based vehicles of various types. Yard planning and organization are critical to the speed of the operation, and efforts are made to ensure that boxes are stacked as close as possible to the vessel or vehicle they are to be transported to next. Thus, the yard is divided into zones along the waterside for each incoming vessel, and zones along the roadside for other forms of transportation. At Tetra, two straddle-carriers work with one waterside crane which is operated by two workers alternating as crane driver and radio man on deck. A fifth worker completes the "gang" and is located with a radio on the quayside. Their functions were explained thus:

One crane these days in our terminal consists of five people, so that's not a lot. So, its two crane drivers because one crane driver can only go for four hours and they have to change, and when the crane driver doesn't drive the crane he stays as radio man deck; and there are two straddle-carrier drivers and a radio man wall who does the administration and the coordination between carriers and crane, so its basically five men that can load and unload a ship [...]. The terminals next door are fully automated [...], that means only two people - the crane drivers - the rest goes automatic. 34

3I. It is not unusual for container shipping lines to establish agreements with competitors on service sharing etc., known as conferences.

32. Bunkering is the term used to refer to taking on fuel stores.

33. Reach-stackers can stack and unstuck boxes up to nine high. Straddle-carriers are driven over boxes and are used to lift them and transport them on to lorries or to or from the waterside. They are highly mobile and move rapidly around the yard.

34. Tetra employee: interview with Sampson. 
Whilst not automated to the extent of its futuristic neighbour, whose yard is devoid of human life and is operated by driverless automated guided vehicles reminiscent of the aliens in the film War of the Worlds, the Tetra operation is high tech and highly computerized. The drive to reduce manual operations in favour of automation continues, and with it is an associated drive to reduce the overall number of employees. This situation appeared to be regarded pragmatically by interviewees. One manager explained:

The future is definitely automation and less people. That is roo per cent definite [...]. Technology is needed these days and improvements with that will continue, because the margins in this industry are extremely small and we have to make money to survive, so we don't want to stop our technical developments. I guess that's the future [...]. Training of course - you have to continuously adjust your organization, so maybe its putting a strain on people more so than before - but that's life. That's the world nowadays. 35

Another whose job involved yard planning and supervision was actively involved in seeking ways to eliminate manual planning in favour of automation. He impassively explained: "If the settings are right you don't have manual planners. If a box arrives it should automatically go to an area somewhere, to a specific floorspace without human intervention. We are still facing two manual planners [...] because of the problems we have." ${ }^{6}$ To facilitate the level of automation introduced at Tetra, considerable investment in ICT has taken place. The terminal has two main-frame computers running in parallel with each other to protect against down time and data corruption. Staff in the control tower ${ }^{37}$ are equipped with PCs running off the shelf software packages designed for yard planning. Straddle-carrier and crane drivers communicate using two-way radios as do the radio men (deck and wall). The straddle-carrier drivers receive their instructions from small hand-held computers in their vehicles, and crane drivers are similarly equipped. Workers operating in the "yard" work as isolated individuals communicating with each other by radio or electronic means, and they are required to work under pressure and at speed. From the vantage point of the control tower, the straddle-carriers and cranes resemble a colony of ants, highly organized, highly mobile, and with a strong sense of purpose. It is quite obviously not a production line, yet it has this feel.

The scene is markedly different at a terminal dedicated to noncontainerized goods. Here port workers swarm over a vessel in teams.

35. Ibid.

36. Ibid.

37. The control tower overlooks the yard and resembles a small air traffic control tower both internally and externally. 
The workers communicate verbally and using sign language; they interact with each other and they interact with seafarers, and the scene resembles organized chaos more than organized production. In Brazil, in the course of ethnographic work aboard a bulk carrier, a stevedore foreman was encountered fishing from the side of the vessel, engaging in casual conversation with passing stevedores and seafarers, whilst observing his team loading forest products into the holds. Such a scene is not only unimaginable but quite simply impossible at a terminal such as Tetra, where encounters with and between workers are more likely to occur inside the terminal building than on the quayside. The workforce at Tetra is thus rendered invisible to the majority of seafarers, just as seafarers are rendered invisible to Tetra employees. The distance between them is relatively short and yet the yard itself acts as a chasm dividing them. The following interview extract is illustrative:

Interviewer: What about the interaction between the sea staff and the terminal staff? Is there any?

Tetra employee: Too little.

Interviewer: You think it should be more?

Tetra employee: I would like to see more, but the thing is that we are sitting here, and to go down to the ship you have to go around [gestures long route circumventing yard]. So it is a distance of [several] kilometres. People don't do it.

Thus, despite encouragement by the company, and even though some terminal staff are ex-seafarers themselves and know some of the senior officers aboard visiting vessels, contact between the two groups of employees is minimal. In the course of collecting ethnographic data aboard noncontainer vessels on relatively stable routes Sampson observed a number of occasions where sea staff (including ratings) were invited ashore by shore-based staff. These groups had come to know each other over a period of time, as a result of their contact in the course of their work. This did not happen at the Tetra terminal, where one employee illustrated the way in which the insulation of the container terminal from the ship discourages such social relations:

Although it is encouraged from here that we have to take the captain out and the company pays, just so the master or the chief engineer has another face and he can talk [...], you don't do it [...] - you can always make time, but I don't go on board and say to a stranger come, we have a bite somewhere. I don't do that. ${ }^{38}$

Thus, the organization of work in container terminals militates against social contact between shore and sea-staff. The space around the ship, the yard, has become controlled, and unauthorized access is prohibited for

38. Tetra employee: interview with Sampson. 
health and safety reasons, and to minimize disruption to operations. Equally, the ship has become a remote and unfamiliar space to shore-side workers, few of whom will touch a deck in the course of their work.

\section{INNOVATION ABOARD AND THE AVAILABILITY OF W ORK}

Whilst Schumpeter's work emphasized entrepreneurship amongst individuals, others, in developing his ideas, have identified innovation and entrepreneurship at the level of the firm, ${ }^{39,40}$ and have argued that innovation is essential for the survival of modern-day shipping companies. ${ }^{\mathrm{I}}$ In this, achieving reductions in employee numbers and increasing competitiveness are seen as primary drivers of innovation replacing the historical pressures of environmental and safety standards and regulation. Some have argued that innovation in shipping has indeed facilitated drastic reductions in crewing levels: "In more recent years, technological change has again become an important factor in shipping with the introduction of new information, computer control, and communications technology which facilitates drastic crew reductions with consequent savings in ship accommodations and other costs." ${ }^{22}$ However, these changes in crewing practices are complex, and are consequently difficult to trace and precisely pinpoint.

The complexity of the relationship between innovation and crew size results from the changing nature and heterogeneity of the shipping industry, and the casualized nature of the seafarer labour market. Whereas the introduction of new labour saving technology or automated machinery at a fixed site ashore often results in sudden and dramatic downsizing, ${ }^{43}$ aboard, it often takes place as a gradual process of attrition. Seafarers on short-term contracts are not generally "sent home" mid-contract but are simply not replaced after they return home for their vacation. Similarly, reductions in crew sizes are rarely obviously dramatic, as they have tended to either coincide with the introduction of new types of vessel (steamships or equally container vessels), or with a general trend of increasing vessel size and increasing freight movement. Thus crewing levels per gross ton

39. Jeffrey G. Covin, "Entrepreneurial vs. Conservative Firms: A Comparison of Strategies and Performance", Journal of Management Studies, 28 (1991), pp. 439-462.

40. Jan Inge Jenssen and Trond Randøy, "Factors that Promote Innovation in Shipping", Maritime Policy E Management, 29 (2002), pp. I19-133.

4I. Ernst G. Frankel, “The Economics of Technological Change in Shipping”, Maritime Policy

E Management, I8 (I991), pp. 43-53.

42. Ibid., p. 44.

43. Van Lente, "Machines and the Order of the Harbour". 
may have declined over time, ${ }^{44}$ but aboard a ship seafarers may be sailing with crews of similar size to those they are generally accustomed to. Equally, seafaring jobs may be periodically redefined by crew managers and ship owners as "cleaning jobs" or specialist tasks for "riding crew", 45 whilst, in reality, the tasks are the same as those that have traditionally been performed by workers classified as, for example, "wipers" or "fitters". As a result, seafarers themselves do not seem to have perceived "drastic" reductions in crewing levels as a quote from a senior officer of a container ship illustrates:

Changes in technology mean [that] somebody thinks we can use less crew members, but that does not correspond to reality. We're still the same [number of] people on board but now they call it maintenance crew [...] and other repairmen and all that, but actually there's still the same number of people on board. The minimum safe manning was years ago, twenty-one [years ago] for example, [...] twenty-eight [people]. Are we twenty-eight people currently? I think so. OK, so we have a special job being performed but we are generally between twenty-one [...] and twenty-five people on board. ${ }^{4}$

This situation of gradual change on board ship contrasts starkly with the dramatic cutting of dock work in Rotterdam when mechanized grain unloaders were introduced. This difference (in experience and perception) was also apparent when containerization began to replace break-bulk cargo transportation. Thus, the Rotterdam dockworkers of the early twentieth century perceived technology as almost representing a "deathblow" for the harbour, as Van Lente in describing one of the strikers' protest songs explains: "The song said that it would make hundreds of workers lose their jobs. It called the machine the image of the employers who had introduced it: hard and cold, it would suck the lifeblood out of the workers even as it sucked the grain out of the ships." 47 By contrast seafarers, when they have staged industrial action, have tended to focus on wages rather than on employment issues connected to innovation, automation, or mechanization. Nevertheless, at sea, as ashore, a number of specific jobs can be seen to have been lost as a result of technological innovation within the maritime industry, and some estimates indicate that crew sizes have dropped by as many as thirty seafarers per ship in the

44. According to some sources, the ratio of seafarers to gross ton has dropped from three persons per 1,000 gt in 1960 to one person per 1,000 gt in 1980 . See Hercules E. Haralambides, "An Economic Analysis of the Seagoing Labour Market", presented to the Fifth World Conference of Transport in Research, July 1989, and quoted in John Spruyt (ed.), Ship Management (London, 1994).

45. Riding crew are usually assigned to a ship in order to perform a particular maintenance or repair task. When the task is completed they are reassigned to a different ship.

46. Officer aboard container vessel: interview with Sampson.

47. Van Lente, "Machines and the Order of the Harbour", p. 80. 
period 1950-1980.48 Most twentieth-century changes can be linked to automation and the change from steam to diesel (e.g. the loss of donkeymen, ${ }^{49}$ some engineers, firemen ${ }^{5 \circ}$ ). However, one recent change has been a direct result of innovation in communications technology and the mandatory introduction of GMDSS. This relates to the job of the radio officer, which has disappeared altogether from the vast majority of vessels.

The unwelcome loss of radio officers has much been regretted by many seafarers, and has had particular consequences for the workload of ship's captains. As one explained:

Well it's [the captain's job] changed a lot because I'm now the radio officer. So we no longer have a radio officer as of three or four years ago [...]. We have an internet-based communication system, and that's new in the last three to four years - and that is a mixed thing for us. It's certainly - the communication is good, and is fast and it's reliable, but it's also provided them [shore-side operations] with the means to pour information at us and vast volumes of information, and sometimes [...] we wish we didn't have so much communication. ${ }^{\mathrm{I}}$

Despite the associated changes to their work and the loss of radio officers aboard, many officers have responded to developments in ICT in positive if not entirely uncritical ways. The reasons for such response are multiple. Developments in information and communication technology have had a global impact which, whilst modulated by variations within and between societies and individuals, have had implications for an enormous segment of the world population. Developments in ICT have come to extend beyond age, employment, and gender distinctions in impacting on the lives of very many members of contemporary societies particularly, but not exclusively, in those societies characterized by affluence. Workers, including many seafarers, are integrated into such ICT-literate and rich societies, and are thus in a position to benefit from innovation as consumers, social actors, and employees. Similarly, however, they are not blind to the extent to which innovation can result in unwelcome change to labour processes and labour markets, particularly in terms of redundancy and deskilling (although the notion of deskilling in the merchant marine is challenged by some)..$^{52}$ In this context, and given the rapid change brought about by technological innovation to the post-

\footnotetext{
48. CETS, Crew Size and Maritime Safety (Washington DC, I990).

49. A donkeyman was an engine-room petty officer responsible for the maintenance and repair of the donkey boiler and engine which was used in providing power for a number of deckside mechanical pieces of equipment, e.g. winches.

50. Firemen were responsible for feeding the boilers with coal and maintaining the generation of optimum levels of steam.

5I. Captain of container vessel: interview with Sampson.

52. Eric W. Sagar, Ships and Memories: Merchant Seafarers in Canada's Age of Steam (Vancouver, I993).
} 
industrial realm of work, the response of workers to date could be characterized as constrained. Certainly, within the shipping industry, mariners have taken a highly rational approach to mechanization, automation, and latterly the ICT revolution. They have not been blind to the disadvantages associated with such technologies, but neither have they generally been reactionary, given the introduction of innovative instruments, machines, or processes. Their attitudes can be gauged not only via interviews but additionally via comments made in the "trade" press. In response to the introduction of GMDSS, for example, with the consequent loss of radio officers, there has been much criticism from merchant officers. One master mariner, in a recent interview for a trade publication, expressed the views of many when he said:

I have yet to be convinced that GMDSS has improved safety of life at sea. I believe that a dedicated radio officer, using the latest technology, would be safer $[\ldots]$. The high number of false alerts speaks for itself - the equipment is not userfriendly [...]. GMDSS equipment should be simple to operate, user-friendly and intuitive. Equipment manufacturers should remember that deck officer GMDSS operators are not communications specialists. 53

His thoughts were echoed by a captain interviewed in Rotterdam, who described how too many alarms on the bridge, including GMDSS false alarms, result in some of them being "screened out" by officers on watch, with the implication that important alarms could be ignored, resulting in the endangering of the lives of the ships' crew or others in distress at sea. She explained:

All the alarms, a lot of alarms on the bridge [...] are just dressing. [They do] not need to be there [...]. They could make a blinking alarm [instead] [...] and you can't stop it [GMDSS] either. It has to go beep-beep for about five seconds; you can't stop it. That's not necessary either [...]. You just [end up in a situation where you] acknowledge all the alarms and you don't even know what they're for. Sometimes an important one goes by - [they're] pretty dangerous all these alarms [...]. It's like all these distresses that are false alarms. 99 per cent of them are false alarms. ${ }^{54}$

Nevertheless, despite their awareness of the impact of the loss of the radio officer on the workload of the captain, most serving seafarers accept this with pragmatism. Their criticisms thus tend to centre on issues of safety and operational concerns, rather than on changes to their personal job descriptions or workloads.

54. Captain of container vessel: interview with Sampson. 


\section{INNOVATION ABOARD AND CHANGES IN THE NATURE OF WORK}

In combining the findings from the pilot study of the Tetra container terminal in Rotterdam and the on-board ethnographic research, it becomes apparent that computerization and the communications revolution have combined in ways that not only make fast vessel turnaround a possibility but have also fuelled innovation and organizational change aboard. In general, ICT has impacted on the work of officers and has had little effect on the daily work of ratings who are mainly engaged in routine maintenance, cleaning, painting, and "chipping". 55

In common with most modern vessels, Tetra ships do not carry radio officers but have replaced VHF emergency communication systems with Global Maritime Distress and Safety Systems (GMDSS) and have transferred much of the work of radio officers to captains, also known as Masters. Masters are thus far more concerned with paperwork and the preparation of records and documents for port officials, customs and immigration officers, charterers, inspectors, and company shore-side workers than they were hitherto. They have had to acquire rapidly a good understanding of computers and computer software, and have seen their role change to be less that of "master mariner" and more that of "vessel manager". Tetra ships carry a considerable number of computers loaded with a range of sophisticated software which monitors and/or controls ballasting, bunkering, freight temperatures, engine-related pressures and temperatures, as well as more prosaic functions such as the ordering of stores and equipment. All officers interact with such systems to some extent, and consequently all have seen a shift from being engaged in more practical manual tasks to carrying out more sedentary monitoring and administrative tasks. For example, the chief engineer of a Tetra "mother vessel" is able to monitor engine pressures and temperatures as well as other relevant information from his/her day room (office), and can thus retain a vigilant yet unobtrusive watch on the work of other engineers throughout the day or (in unusual circumstances) night. Remaining in the office, the chief is able to deal with the large volume of paperwork and record-keeping required by the shore-side office, and in terms of the routines of daily life has seen a shift in role from that of expert and often "hands-on" engineer to somewhat remote administrator. The chief officer's role has also been transformed. Previously, the chief officer had, as a central feature of his/her work, responsibility for cargo stowage and stress and stability calculations. Aboard the modern Tetra ship, however, the chief officer is merely required to check stowage plans and stability and stress calculations prepared ashore after they are presented,

55. Chipping rusting paint prior to repriming/painting is a common task for ratings. 
on the vessel's arrival, on a floppy disk. An additional and surprising associated change in the role of chief officers aboard larger Tetra ships is the requirement for the chief officer to oversee bunkering, a job normally undertaken by a member of the engineering team and not traditionally regarded as associated with the work of chief officers at all.

Such changes in the organization of work have been accompanied by changes in the way in which tasks are carried out. These are perhaps most obvious on the bridge of modern container vessels where the Tetra ships are typical in carrying ECDIS and the most modern integrated navigation systems. These free the navigators from reliance on paper charts although, for the time being, these are still carried and manually corrected on board. Skills once the stock in trade of seafarers, such as using a sextant to take sights, and communicating to other vessels regardless of the nationality of their seafarers using Morse lamps, have been, or are being, lost whilst new skills relating to the use of information and communication technology are rapidly being acquired. Such changes have fuelled demand in some sectors of the industry for dual-purpose officers trained not for either the engine or the deck-side but for both. Such officers have been employed and trained for some decades, but innovation and change in the latter part of the twentieth century has led to a renewed interest in the production of dual-purpose officers and their introduction by an increasing number of companies, including the Tetra shipping line.

Seafarers may have more opportunities than many to participate in the introduction of innovative technologies aboard. Ships are relatively unique environments and it is often only in the real world of the ship that many maritime innovations can be truly tested (although simulators are increasingly used to test new navigational aids and equipment). The early limitations of radar and its implication in a number of maritime accidents is illustrative.

Many shipping companies are run by ex-seafarers who understand the importance of user feedback from the ships, and some companies have gone so far as to introduce websites where seafarers can comment on any aspect of their job or life aboard. That seafarers are willing and able to comment was apparent in our research. Their response to innovation and change was far from dismissively negative but was generally thoughtful and constructive. Some, who preferred more practical rather than computer-based activities, welcomed developments in radar, for example. Others saw the benefits of innovation whilst being concerned about what might be its "side effects", for example information overload. Several queried the wisdom of losing traditional skills of navigation, but equally recognized the extent to which mistrusted new equipment can soon be regarded as the norm and accepted and relied upon, whilst others differentiated between established reliable equipment and other hard and software that could not be trusted. The following remarks are illustrative: 
There's more, yeah, more communication [...] [it's] not so good [...] no news is good news! There's too much and I'm an idiot with paperwork. More papers make me more an idiot. That's a personal thing. Some people are very good with papers. I'm lousy [...]. If I knew there was so much paperwork in this job I would never have chosen it. Never in my life [...]. When I first started I was in Coasters sailing round the Faroe islands, Malta, nobody looked at papers [...]. Never anybody! [...] How I see it with the paperwork, it's a jungle [...] which for me is not transparent. Too many systems, I can't oversee it [...]. Generally I like to sail. [The] best bits [of my job] are where you get in contact with the elements [...]. Seamanship. This is not seamanship [rustles papers] this is horseshit! ${ }^{6}$

We can send a telex in the morning questioning about a reefer [refrigerated container] and then in the afternoon we have the answer. So that has been better because in the old days the radio officer, he couldn't get in touch of something ashore $[\ldots]$ now you can take this phone [indicates satellite telephone] and call directly to the person [...]. All the monitoring system, in the engine department you can monitor the main engine. This [pointing to a computer screen with gauges and diagrams] is the main engine, all the temperatures [are shown] here and the pressures all the time [...]. So it has been a little bit easier. On the other hand $[\ldots]$ you can have a lot of information now but not using them for anything. 57

If it [a computer or other piece of ICT] doesn't work all of a sudden you can, might, make a mistake 'cos you've gotten used to it [...]. We don't trust it [indicating a refrigerated container monitoring computer on board] because we've always experienced it makes mistakes, so even though it works nobody trusts it completely. So we always check [physically using traditional measuring devices]..$^{8}$

The generally pragmatic response by seafarers to innovation in ICT is likely to be due partly to the fact that many historical technological changes have reduced the dangers that seafarers are exposed to, and have dramatically improved working and living conditions aboard. The transition from sail to steam removed a number of hazardous tasks (for example, those involving climbing highly unstable rigging to release or secure sails), and the move from steam to diesel engines must have surely been welcomed by the firemen who had to fuel the boilers on steam powered vessels. Sagar illustrates this point vividly in his account of such work explaining:

Firemen, who are sometimes called stokers, had one of the hardest jobs ever to be endured by human beings. Their job was to keep the boilers fired by keeping the coal fires burning as cleanly as possible. Working near the boilers, they came close to burning alive, especially in the tropics, where fresh air would not get

56. Container vessel officer: interview with Sampson.

57. Ibid.

58. Ibid. 
down the ventilators, and temperatures could reach I30 or I40 degrees Fahrenheit. Trimmers worked in the dark, dusty coal bunkers, shovelling coal and moving it about in wheel barrows [...]. In the British merchant marine in I 893, forty-one firemen or trimmers committed suicide. In I 894 forty-nine firemen or trimmers committed suicide. Driven mad by the heat they would throw themselves into the sea. 59

The introduction of information technology aboard and its subsequent improvement has similarly resulted in safety gains. It has also led to a decline in the number of repetitive and monotonous tasks officers routinely carry out. For example, aboard early container ships the manual entry of container numbers into a software programme was required. This is now fully computerized, pleasing many chief officers, as one container vessel captain explained:

I've never been where the computers have broken down, because if the computers break down I think we would just have to go ashore and do our calculations. We couldn't possibly take every container and calculate the old fashioned way. But about three or four years ago we just had to put every container on the computer. That would take a long time for the chief officer and now he just gets a disk to check. That's much better. ${ }^{60}$

The advantages of new technology are therefore, generally appreciated by seafarers. However, many also highlight the extent to which new technologies have eroded some pleasurable aspects of their work. On container vessels, for example, load and stress calculations are done ashore and the ship is merely presented with a "soft" copy of a cargo plan on disk to check. Similarly, ship-board cranes are no longer utilized nor carried, removing responsibility for their maintenance from vessel crews. For many chief officers cargo handling, and stress calculations alongside crane "gear" maintenance are amongst the more interesting aspects of work at sea, and some go so far as to avoid working on container ships because the nature of the work has changed in this way. One captain of a Tetra container vessel, for example, tried to avoid being moved to container ships for a number of years for this very reason. Despite pressure from her company, she preferred to remain aboard her company's less prestigious vessels trading in and around Africa. She explained:

I've been on the African boats - they're not as large as these - where we get to arrange a little bit where the cargo goes and we have a say in it when it's loaded, and that's more interesting than these boats [...]. Yes, I've been on those boats for about eight years and enjoyed very much. Here the Mate doesn't have very much to do with where they load and when, and on the Africa boats they have their own crane. So that's more like it's old-fashioned and I learned very much from

60. Captain of container vessel: interview with Sampson. 
that [...]. They [the company] always want to move us around and they tell me I'd better go and try these [container ships] and I think, "Oh No, I want to stay". That was because it was more interesting in port and we felt more useful. ${ }^{6 \mathrm{I}}$

\section{INNOVATION ABOARD AND THE EXPERIENCE OF TIME AND SPACE}

Whilst changes to crewing levels brought about by innovation are difficult to pinpoint and may be largely un-noticed by seafarers, changes to the nature of work on board, the speed at which it is carried out, and its reorganization are far clearer, as is the impact of containerization on the turnaround time of ocean-going as well as coastal vessels. Evidence collected from the Port of Rotterdam suggests that increases in numbers of crane moves per hour achieved by modern container terminals have translated into faster vessel turnaround, and that this process is ongoing and relatively rapid. Thus over as short a period as five years it is possible to demonstrate a significant, though not dramatic, increase in the speed with which ships are able to get in and out of ports (see Table 2).

Kahveci's research in Sandhaven ${ }^{62}$ also demonstrates the speed at which current vessels can load and discharge, arrive and depart, from modern port terminals. His data suggest that an average port stay today accounts for approximately I 3 per cent of a vessel's working time, as opposed to 50 per cent thirty years ago. ${ }^{63}$ This inevitably impacts not only on vessel operators and their profit margins but also on the work and welfare of dockers ${ }^{64}$ and seafarers.

For seafarers, innovations that allow ships to turnaround in port faster impact on access to shore leave, and land-based facilities and amenities. This can prevent poorly paid ratings from accessing cheap telecommunications; it prevents seafarers from purchasing necessary items, which may have particular implications for women seafarers, ${ }^{65}$ and it has more general implications for social isolation and associated mental health issues. ${ }^{66}$ Our ethnographic work aboard ships of different types has revealed the extent

\footnotetext{
6I. Ibid.

62. This is a fictitious name for an existing port facility.

63. Erol Kahveci, "Fast Turnaround Ships Impact on Seafarers' Lives", Seaways, (March 2000), pp. 8 - I 2 .

64. In Rotterdam, evidence is emerging of health problems such as back trouble amongst straddle-carrier drivers. This is believed to result from the "human-unfriendly" design of the carriers.

65. Phil Belcher et al., Women Seafarers: Global Employment Policies and Practices (Cardiff, 2002).

66. Helen Sampson and Michelle Thomas, "Health and Safety at Sea: Social Factors, A Neglected Dimension", Proceedings of International Symposium on Human Factors on Board $200 I$ (Bremen, forthcoming).
} 
Table 2. Vessel turnaround times in the Tetra Terminal: 1997 and 2002*

\begin{tabular}{lccc}
\hline Year & Mean time (hours) & Median time (hours) & No. of vessels \\
\hline 1997 & 23.19 & 22.00 & 37 \\
2002 & 20.50 & 19.00 & 26 \\
\hline
\end{tabular}

Source: Port of Rotterdam Authority

* To facilitate comparison the port of Rotterdam supplied data for all vessels arriving and departing in the first and last weeks of March 1997 and 2002. The figures here are based on extrapolated data for Tetra vessels in these periods.

to which seafarers look forward to shore leave and the importance it holds for life on board. When seafarers are able to go ashore in groups, shoreleave acts to strengthen social solidarity aboard. Additionally, it breaks up the monotony of everyday life aboard and gives seafarers something to talk and laugh about once they are back at sea.

On container vessels, some companies have compensated for lack of shore leave by shortening lengths of contracts for sea staff. This leaves seafarers feeling more pragmatic about denied opportunities for shore leave than might otherwise be the case, as the following comments made by senior officers (who generally have the shortest contracts) aboard different vessels in Rotterdam show:

We have one place in Long Beach where we're almost three days because they totally empty the ship and load [it again] [...] so that's very nice and people enjoy it [...] everybody gets the chance to go ashore [...]. When we are out for only three months at a time [the length of the transglobe voyage cycle and the senior officers' contracts] its not so important, but everybody looks forward to Long Beach and everybody also looks forward to Hong Kong because we're there for twenty-four hours [...]. They look forward to it but I don't know what it would be like if we didn't [have those shore-leave opportunities in the I3-week tour]. I guess I haven't thought about the importance of that. ${ }^{67}$

I was always on liner services then [about twenty-five years ago when he was first at sea] [...] as opposed to tramp services [which usually spend longer in ports for a variety of reasons]. And the liner services had schedules and, at least in my experience, they pretty well maintained them. But the port time was certainly greater. Anywhere from one to three or four days [...]. I would say more typically the port times were three to five times longer and a lot less cargo and the ships were smaller and we might spend all day on eight or nine hundred tons of cargo, where in one hour [nowadays] one crane can load that [...]. The quality of life here [...] has evolved over time and we've adapted to it. [...] going ashore is something, it would be nice to do but you don't necessarily expect that it will happen [...]. I'm not saying that's a good thing but it's what's evolved [...] there's

67. Captain of container vessel: interview with Sampson 


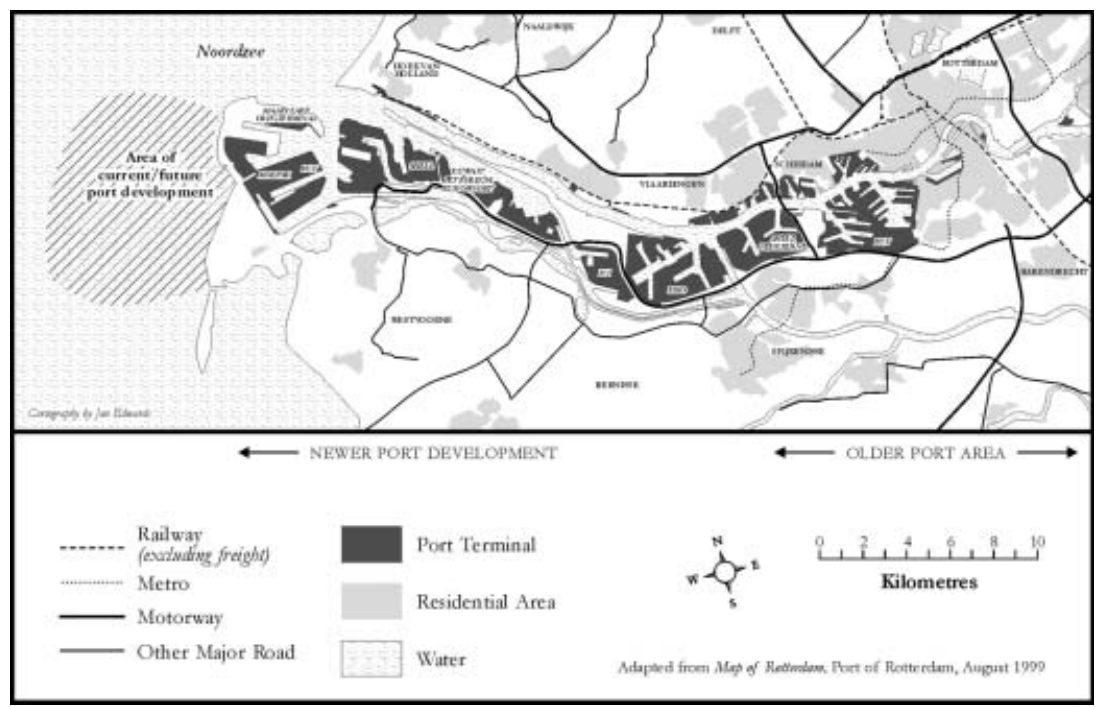

Figure 2. Map of Rotterdam Port showing "seaward drift" of modern development and public transport routes.

Adapted from Map of Rotterdam, Port of Rotterdam, August 1999, cartography by Jan Edwards

times when you think it's not [...] that it isn't very good from our side [...]. [But] we're well paid, we have generous vacation schedules so I think we're willing to put up with it. ${ }^{68}$

Whilst the lack of time available for shore leave is probably the major reason for seafarers remaining on board for most of their contract period, the location of terminals also frequently militates against shore leave. Modern terminals and their space-hungry requirements for water frontage and excellent transport infrastructure have driven change in the spatial layout of modern port cities. These have altered as newer port facilities have been constructed in increasingly geographically remote districts, often at a great distance from population centres. The port of Rotterdam provides a good example of this tendency. Its oldest port terminal buildings and berths, some of which have fallen into disuse, are located very close to the city centre, whilst its most modern container terminals have been constructed up to $60 \mathrm{~km}$ away at the mouth of the river (See Figure 2).

Travelling from the new terminals to the centre of Rotterdam takes approximately one hour by car and costs around $€ 200$ for a return trip. 
The situation is compounded by a total absence of public transport with the result that seafarers report never going ashore there. As one explained:

I would never consider going to shore in Rotterdam which I did before, because it is too far away [...]. Many years ago the terminal was in Rotterdam so maybe two hours sailing upstream [from the current terminal] [...]. At that time it would be ten to fifteen minutes [to get from the port to the city centre], [...] ten minutes by taxi, even a tram you could take [...] now I don't know probably three quarters of an hour [...]. It's too far away. It's too expensive! ${ }^{69}$

These circumstances impact upon seafarers in different ways. Better-paid officers can probably afford to take taxis to the city centre, but are generally unable to leave the vessel as a result of their responsibilities. Whilst ratings may be granted shore leave but find such extravagance prohibitive. Thus, in varying ways, distance and time combine to prevent seafarers accessing the wider world when their ships berth at such modern terminals.

Fast vessel turnaround, facilitated by containerization and innovation in information and communication technology, would therefore seem to have a number of disadvantages for serving seafarers. For those working aboard vessels with short turnaround times, the spatial sphere accessible to them has shrunk as a result of their isolation from towns and cities and the speed with which they are in and out of port. Concurrently, changes in working practices and in the use of space in modern cargo terminals have combined to limit seafarers' contact with other related workers, widening the gulf between them and land-based society. Thus, the vessel has become more like a prison then ever..$^{70}$ The experience of transnational life has traditionally been a central feature of the lives of seafarers, as they have had the opportunity to interact with others of different nationality and culture in ports around the world. Such transnationality is disappearing, however, just at a time when it is becoming a major part of the lives of many others engaged in different occupations. Paradoxically, for a workforce engaged in an occupation driving the process of time-space compression, the lives of today's seafarers are becoming more inwardly focused, as they are increasingly trapped in the byperspace characteristic of the internal territory of their vessels. ${ }^{71}$

Companies have attempted to ameliorate such disadvantages for some seafarers, particularly European/US officers, and have introduced shorter

69. Ibid.

70. Tony Lane, "Being on a Ship is Being in Jail", Naftika Chronika, November (1998), pp. 8889.

7I. Helen Sampson, "Transnational Drifters or Hyperspace Dwellers: An Exploration of the Lives of Filipino Seafarers Aboard and Ashore", Ethnic and Racial Studies, 26 (2003), pp. 253277 . 
voyage contracts and longer leave-periods. For ratings, however, and seafarers generally drawn from world regions other than Europe, North America, Japan, and Australia, such provisions have not been adopted. These seafarers are put under some significant strain and risk as a result of the new processes introduced in shipping freight at fast speed around the world..$^{2}$ They describe long periods of boredom and monotony and a requirement for mental "toughness",

I describe [a] seafarer's life as a boring one. I'd say boring [...] there is no excitement also [...] you have to, in seafaring you have to be tough, you [need] strength to be [...] [there is] pressure so you have to be tough, [...] [which] means you [...] are strength [strong] enough to stand by yourself. [It is] boring because you are very isolated. [You don't know] what happen [...] what is happening in your country [...], what is happening in your family? 73

"Oh, a seafarer's life, a seafarer's life sometimes is boring and then boring and then [...] I cannot think, boring ahhh...". ${ }^{74}$ And they suggest that it is very hard for people ashore to imagine the lives of people at sea. One seafarer approaching the end of a twelve-month contract described how:

If you try to explain to them [ashore] that this is the situation they wouldn't believe you. They say that this man is lying [...]. I don't like to be explaining to people about my job - yeah - because if I started explaining to you, you wouldn't believe [...]. My job is very tedious, very hard working. [I] spend 365 days on board everyday working, everyday working, everyday working, until the end of the trip [...]. I am expecting now to go home any trip maybe next loading/discharging. [...]. My heart is now all at home. Now want to go I want to leave here $[\ldots]$ the sea so it's only time, it's only time now $[\ldots . . .75$

Others described how they wouldn't recommend a seafarer's life to their friends or children: "If I talk to some stranger I don't influence him to come, to become a seafarer unfortunately its difficult you know. Every time you come alone, come alone, even my little boy when he grow up I don't like him to become a seafarer somehow." ${ }^{6}$

I don't know if he [my son] will come on board. I would like it if he didn't have to because it's a hard life and I don't want him to suffer like me, I don't want him to suffer like I've suffered [...]. Life on ship is very lonely, so I don't want him to suffer like that - he is supposed to be with his wife and children not like me. When I am here I miss my children, it's hard working on ships, very hard.77

72. Sampson and Thomas, "Health and Safety at Sea".

73. Able-bodied seafarer: interview with Kahveci.

74. Able-bodied seafarer: interview with Sampson.

75. Ordinary seaman: interview with Bloor.

76. Bosun: interview with Sampson.

77. Electrician: interview with Sampson. 
If seafarers have not recently benefited from the speed up of cargo operations or vessels themselves in the late twentieth and early twenty-first centuries, we might expect that they will at least have benefited from the revolution in telecommunications and the introduction of the internet. In some cases this seems to be the case. Whilst close to the shore, seafarers can use their own personal mobile phones, and "texting" is often popular with less well-off individuals. Officers, and particularly the captain, are most likely to benefit from access to company-funded communication systems. They can often access vessel mobile telephones, and may be granted free e-mail for their own personal use aboard. Aboard Tetra ships, all crew members were, in principle, granted free on-board e-mail access. Such access is being phased in by a number of companies and is clearly a positive development. However, even this kind of provision often fails to produce uniform access for a number of reasons. A significant number of seafarers' families do not have, or cannot afford, access to e-mail, and even where they can they may encounter further barriers. For example, Thai workers aboard Tetra vessels (also on the longest voyage contracts) were unable to read or write in English, and as a result of the difference between Thai and Roman script were unable to use English-language keyboards. Thus, even if their families had internet access they were unable to make use of the free e-mail provision aboard.

This, like the example of shore leave, highlights the differential impact of technological innovation upon seafarers and the contradictions inherent in a time-space compressed world. The compensation for slower forms of communication in the I960s and I970s was longer periods of shore leave, where seafarers could see and experience different countries and cultures and meet and interact with different peoples. Today, a seafarer working a nine-month contract aboard a fast-turnaround vessel, with three months vacation a year, may in his working life see less of the world than his nineteenth-century counterpart on voyages of months without sight of land, but ashore in different parts of the world for similarly extended periods.

\section{CONCLUSIONS}

Shipping, as a form of modern transportation, both drives and is itself effected by the forces that have been described by Harvey and others in producing time-space compression. Paradoxically, the workers employed on ships experience such compression as constraining rather than liberating, in terms of their access to the wider world. If the global village represents the notion of the world on your doorstep to some, for seafarers the village has become a remote one, largely inaccessible and imaginary. New technology has changed the world of seafarers in some positive ways, offering increased safety in navigation and, often, more comfortable 
working conditions. It has also impacted negatively upon their working lives. Seafarers aboard vessels utilizing modern container terminals are rarely able to go ashore, and have little direct contact with "outsiders" in the course of their voyage contracts. They have thus seen their spatial worlds diminish. Whilst aboard traditional vessels, seafarers today might still have the opportunity to "see the world" from time to time, the visible world of the seafarer aboard a container vessel is largely confined to the steel clad interior of his/her ship.

The response of seafarers to such changes aboard appears to be nuanced and complex. They may recognize some of the disadvantages of innovation (for example the loss of the radio officer, increased use of computers and paperwork), but like Tatsuno ${ }^{78}$ and Yasuda's ${ }^{79}$ workers in Japan, they nonetheless contribute to the process of technical and organizational innovation. In the case of seafarers, this is achieved in the forms of critiques of unsatisfactory change (such as the introduction of GMDSS) in the trade press, via professional bodies (e.g. the Nautical Institute), and directly to companies, suggestions for positive change (via company websites and direct interaction with shore-side personnel), and support for changes perceived as effective (e.g. better ship-shore communication, and the computerization of container records). Furthermore, the shipping industry is organized in such a way that it is often seafarers or ex-seafarers who drive change aboard ships from temporary or permanent positions ashore in shipping companies and in related services such as stevedoring. In this the Tetra terminal is illustrative:

We have quite a lot of seafarers in the terminal, there are a lot of former seafarers. First of all seafarers, they normally like something close to the ships, like the waterfront industry. Many seafarers at some stage like to get ashore and then they get a job which relates to what they do. And the approach most seafarers have is very good because it is like being on a ship, when the ship is sinking you don't go for a coffee break. That's the approach we need in this business. ${ }^{80}$

The full complexity of the response of seafarers to the possibilities offered by new technologies is captured memorably in a poem written by a comparatively modern mariner (J.F.K.) and published in I977. The poem is titled "Ships to Come", and incorporates the following verses:

Our engineers sleep by day.

The crew are drunk on lager.

The Mate on watch neglects his sight,

To read The Forsyte Saga.

78. Sheridan Tatsuno, Created in Japan: From Imitators to World-Class Innovators (New York, 1990).

79. Yuzo Yasuda, 40 Years, 20 Million Ideas: The Toyota Suggestion System (Cambridge, MA, 1991).

80. Tetra employee: interview with Sampson. 
What kind of ship is this? you say,

Where things seem so erratic.

Our craft is of some future day,

Entirely automatic.

Of rust you will not see a bit,

For everything is plastic.

And if by chance a rock is hit,

We'll bounce off like elastic.

Though work is nil, we still do rave

'Gainst sea life with each breath.

For if we aren't bored to the grave -

We'll drink ourselves to death. ${ }^{8 \mathrm{I}}$

Here, the benefits to seafarers of less work, more leisure time, less stress, and increased safety are all humorously highlighted and attributed to various forms of innovation. Equally however, J.F.K. pinpoints some of the drawbacks of innovation at sea in terms of quality of life and job satisfaction. In this the potential for automation and the application of technology to deskill work ${ }^{82,83}$ is brought into stark relief.

What the poet did not anticipate in his vision of the future, and we would argue to be of equal importance, is the extent to which innovation in shore-side cargo operations has impacted on the life and work of seafarers, and indeed port workers. The role of some seafarers has been changed by such innovation (for example the chief officer), but containerization and the fast vessel turnaround it has facilitated, along with the location of modern port terminals has impacted, albeit differentially, on all seafarers working aboard such ships. Speed up of cargo operations and changes in the utilization of, and access to, space have changed the working environment, spatial worlds, and temporal contexts of seafarers in unanticipated ways that have been negative more often than positive. Such change has had significant consequences for the lives of seafarers, as well as for their work, yet there has been little resistance to its introduction. This may be partly attributed to the fact that even amongst relatively small crews (of twenty to twenty-five) it is evident that the impact of technological innovation is experienced differently depending on both the rank and nationality of seafarers. Nevertheless, it would be inaccurate to suggest that ratings rather than officers suffer as a result of such change. The work of officers has been affected by innovation more than that of ratings, officer positions have been lost as a result of innovation, and it is

81. Abridged from Ronald Hope, Voices from the Sea: Poems by Merchant Seamen (London, I977), p. 58.

82. Harry Braverman, Labour and Monopoly Capital (New York, 1974).

83. Mike Noon and Paul Blyton, The Realities of Work (Basingstoke, I997). 
frequently officers who, due to their responsibilities aboard, have the least opportunities for shore leave. As one first engineer aboard a tanker put it:

Ah you see these days, these days when you approach a port you approach a problem $[\ldots]$ normally we discharge for twenty-four hours, and this twenty-four hours is my worst twenty-four hours because I have the entire plant working down below [...]. There is no way I can go outside [...]. It is not really worth it any more $[\ldots]$ too much hassle, too many problems, too many things, you know! ${ }^{84}$

Nevertheless, officers (depending on nationality) have longer leave periods and work shorter voyages than ratings; their income is generally higher than ratings (although ratings in some companies may be paid more than junior officers in others), and they are more likely to have access to e-mail and mobile telephones aboard. They are thus more likely to experience the time-space compressed world they are operating in positively. For many ratings it would seem that time-space compression makes the world less rather than more accessible, limiting rather than expanding their spatial and communicative horizons whilst distorting time in such a way that periods spent aboard drag on interminably.

84. Engineer: interview with Sampson. 